\title{
Australian Journal of

\section{Promotion of maize growth using endophytic bacteria under greenhouse and field conditions}

\author{
Laiana Lana Bentes Lobo, Roberta Mendes dos Santos, Everlon Cid Rigobelo*
}

\author{
Programa de Pós-Graduação em Microbiologia Agropecuária da Universidade Estadual Paulista "Júlio de Mesquita \\ Filho"/Unesp Departamento de Produção Vegetal, Via de Acesso Paulo Donato Castellane s/n, 14884-900 \\ Jaboticabal, SP, Brazil
}

\section{*Corresponding author: everlon.cid@unesp.br}

\begin{abstract}
The effect of Bacillus subtilis isolates before being used as inoculants is very important. They present various impacts on promotion and characteristics of plant at different stages of growth. This experiment was carried out on maize under greenhouse conditions with eleven treatments of endophytic bacteria and three repetitions. The better isolates under greenhouse conditions were used in the field experiment with four best treatments and six replicates. The traits evaluated under both conditions were height, shoot and root dry matter, and the nitrogen and phosphorus content in the plant and soil and the total number of bacteria in the soil. Under greenhouse conditions, the groups that received Bacillus spp. showed higher amount of soluble phosphorus and total numbers of bacteria compared to control. Under field condition, isolate BS-290 increased the nitrogen and phosphorus concentrations in shoot dry matter, phosphorus concentration in dry soil and the total number of bacteria in the soil, compared to the control. Isolate BS-320 increased the phosphorus concentration in plants and maize yield, which strongly suggests its use as a biological inoculant for maize crops. BS-248, BS 290 and BS-320 isolates promoted the highest maize growth, compared to the other isolates. The results showed that Bacillus subtilis isolates that promote plant growth did not increase similar traits in all plants and the behavior has been highly isolate-dependent. This finding shows that the isolates had a preference and certain specificity on each individual trait.
\end{abstract}

Keywords: Bacillus subtilis, phosphorus solubilization, nitrogen-fixing, inoculation.

Abbreviations: SDM_shoot dry matter; RDM_root dry matter; CFU_colony forming units; IAA_indole acetic acid; PSM_phosphate solubilizing microorganisms.

\section{Introduction}

Brazil is the third largest maize producer and the second largest exporter worldwide, making this country a great competitor of the USA and China according to the USDA (2016). Maize is considered as one of the main cereal crops based on its production, especially as a winter crop (autumn and winter). This productivity demonstrates the strategic importance of Brazil offering this product, considering the increase in maize worldwide (CONAB, 2018).

To maintain a high maize crop yield, fertilizers rich in nitrogen and phosphorus have considerable economic importance due to their direct relationship with production costs. Under certain conditions, fertilizers can have environmental impacts such as soil salinization, underground water contamination and river eutrophication (Nguyen et al., 2019). Considering these factors, it becomes crucial to search for strategies to reduce the use and improve the absorption efficiency of fertilizers without reducing yield or promoting environmental damage.

In the search for alternatives to reduce this problem, many advances have used microorganisms that are able to fix nitrogen in the soil and solubilize phosphorus for plants (Knoth et al., 2013; Zafar et al., 2012). In this context, the use of plant growth-promoting rhizobacteria (PGPR) is promising. The benefits can occur directly on plant growth and indirectly by reducing the incidence of phytopathogens (Abdallah et al., 2017).

Among the plant growth-promoting rhizobacteria, some species are able to enter the plant through the stomata and roots to become established as endophytes (Azevedo, 1998), which can be classified as endophyte plant growthpromoting rhizobacteria. Although free-living rhizobacteria and endophytic bacteria are living in different ecological niches but they use similar mechanisms to promote plant growth (Doty, 2013). PGPR can promote plant growth through several mechanisms, such as nitrogen fixation, phytohormone production, siderophore synthesis, and phosphorus solubilization. Furthermore they have indirect benefits to plant development, such as biocontrol and disturbing quorum sensing (Bhattacharyy and Jha, 2012)

Among PGPR, the genus Bacillus is comprises diverse species of rhizospheric and endophytic bacteria with the ability to synthesize phytohormones that can favor root growth by increasing root hair (Angulo et al., 2014). Moreover, their application to maize can contribute to plant growth, development and nutrition (Araujo and Guerreiro, 2010; Lin et al., 2018). Bacillus spp. are gram-positive bacteria that 
produce endospores resistant to adverse conditions, such as high temperature, solar radiation, and dehydration, which contribute to their use as agricultural biofertilizers (Bergey and Holt, 1994). Thus, the use of Bacillus spp. as a biological inoculant is an alternative to increase fertilization efficiency, aiming to reduce the use of mineral fertilization.

Thus, the present study evaluated the effect of endophytic Bacillus amyloliquefaciens, Bacillus subtilis and Bacillus velezensis bacterial isolates as plant growth promoters in maize crops under two condition of greenhouse and field.

\section{Results and Discussion}

\section{Traits measured}

The experiment showed that some bacterial isolates significantly affected $(p<0.05)$ plant height and SDM (Figures $1 \mathrm{~A}-\mathrm{B})$. The increase in plant height was obtained with BS$320(97.6 \mathrm{~cm})$, whereas the plant height in the control was $76 \mathrm{~cm}$. Plants inoculated with BS-263 were shorter than the control plants.

For SDM and RDM, significant differences were observed between BS-320 and BS-248 isolates and the control. For SDM, the BS-263 isolate resulted in a lower height than the control (Figures $1 \mathrm{~A}, \mathrm{C}$ ).

Usually, plant height, SDM and RDM are promoted by the presence of phytohormones. Although phytohormones promote plant growth, some microorganisms produce these compounds to benefit themselves. Phytohormones increase the plant root contact surface, allowing considerable contact between plants and microorganisms, increasing the efficiency, by which plants obtain nutrients and the carbohydrates from plants. Increased RDM is a direct consequence of the action of phytohormone-producing microorganisms on roots, which promote an increase in root efficiency to obtain water and nutrients from the soil (Wang et al., 2010; White et al., 2014). Interestingly, the BS-263 isolate reduced plant growth. This result was unexpected since BS-263 is also a $B$. subtilis isolate with many characteristics of plant growth promotion, including IAA production.

\section{Phytohormones}

An in vitro test is necessary to determine the abilities of microorganisms (Rocha et al., 2017). In the in vitro test, the BS-320 isolate produced $12.41 \mu \mathrm{g}$ of IAA mL ${ }^{-1}$, whereas the BS-263 isolate produced $11.32 \mu \mathrm{g}$ of IAA mL ${ }^{-1}$ (data not shown). However, in vitro results sometimes do not occur under soil conditions. Interestingly, the BS-263 isolate, even as an IAA producer, limited plant development under soil conditions.

Some results regarding the use of plant-growth microorganisms are inconsistent (Gouda et al., 2018). Certainly, this inconsistency occurs due to natural variation in the parameters analyzed. Many studies are needed to understand how isolates with many plant growth-promoting characteristics can inhibit plant growth. These isolates under specific conditions likely act as plant competitors via nutrient uptake. The plant and BS-263 interaction was competitive.

Root microbiota members appear to serve additional host functions through the acquisition of nutrients from the soil for plant growth. Rhizodeposition appears to fuel an initial substrate-driven community shift in the rhizosphere, which converges with host genotype-dependent finetuning of the microbiota profiles in the selection of root endophyte assemblages (Bulgarelli et al., 2013). These results strongly suggest that slight genotypic differences among isolates, including their soil establishment and plant interaction abilities are responsible for the different plant growth levels promoted by each isolate. The abilities of these isolates, such as IAA production, nitrogen fixation and phosphorus solubilization are important but do not guarantee plant growth promotion.

The interactions between plants and microorganisms are influenced by a wide variety of factors, such as genotype, growth state, physiological status, plant tissue type, agricultural practices, and environmental conditions, such as temperature, water availability and nutrients (Compant et al., 2010). More studies are needed to understand the different effects of bacterial isolates of the same species on plant growth promotion.

The chlorophyll content varied from 15.34 to $35.17 \mu \mathrm{g} \mathrm{mL}^{-1}$, and the nitrogen content in SDM varied from 2.10 to $3.12 \mathrm{~g}$ $\mathrm{kg}^{-1}$. However, there was no statistically significant difference $(p<0.05)$ among the treatments for either parameter.

Plants that received BS-320, BS-290 and BS-248 isolates presented higher nitrogen content in the roots, compared to control plants. Interestingly, the same isolates that promoted higher RDM also promoted higher nitrogen content in the roots, except for the BS-290 isolate for RDM (Figure $1 \mathrm{C}$ and Figure $2 \mathrm{~A}$ ). Moreover, the BS-320 isolate promoted higher SDM (Figure $1 \mathrm{~B}$ ). Under field conditions, higher nitrogen contents were promoted by BS- 248 and BS290 (Figure $3 \mathrm{~A}$ ). These results show that some isolates similarly promote high RDM, SDM and nitrogen contents. There is a positive correlation between these parameters and the presence of phytohormones produced by microorganisms. Phytohormones are organic substances that can promote, inhibit, or modify the growth and development of plants at low concentrations (Damam et al., 2016). Phytohormones promote root cell proliferation by overproducing lateral roots and root hairs with a concomitant increase in nutrient and water uptake (Sureshbabu et al., 2016). In this context, the BS-320 isolate was the most competent.

\section{P content}

Regarding the P content in SDM and in the soil, BS-320 and BA-001 isolates promoted the highest $P$ content for both parameters, whereas the BS-290 isolate promoted the highest $\mathrm{P}$ content in soil only. Under field conditions, the highest $\mathrm{P}$ content in SDM was promoted by BS-320 (Figure 3 $B)$, whereas for BS-290, there was no statistically significant difference among treatments for the $\mathrm{P}$ content in the soil (Figure $3 \mathrm{C}$ ).

Phosphorus is the second most important nutrient after nitrogen and is required for plant growth. This nutrient is an essential element in all living systems, and phosphatesolubilizing microorganisms (PSM) play a very important role in phosphorus nutrition by enhancing its availability to plants through its release from inorganic and organic soil 
Table 1. Description of the treatments.

\begin{tabular}{lll}
\hline Treatments & Isolates & ID code \\
\hline 1 & Bacillus amyloliquefaciens & BA-001 \\
2 & B. velezenses & BV-188 \\
3 & B. subtilis & BS-248 \\
4 & B. subtilis & BS-263 \\
5 & B. subtilis & BS-274 \\
6 & B. subtilis & BS-287 \\
7 & B. subtilis & BS-290 \\
8 & B. subtilis & BS-291 \\
9 & B. subtilis & BS-309 \\
10 & B. subtilis & BS-320 \\
11 & Control & Control \\
\hline
\end{tabular}

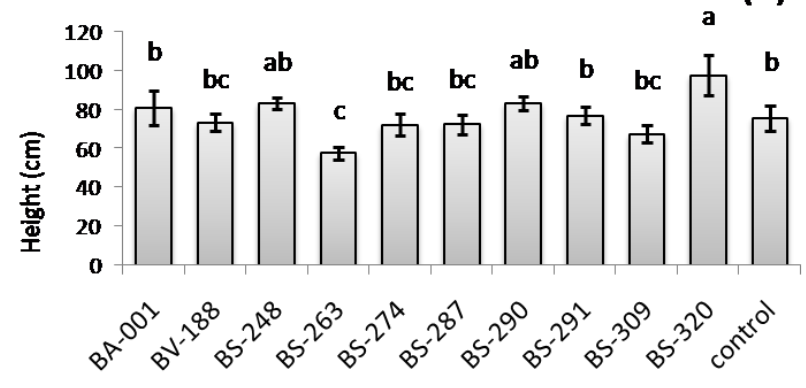

(B)
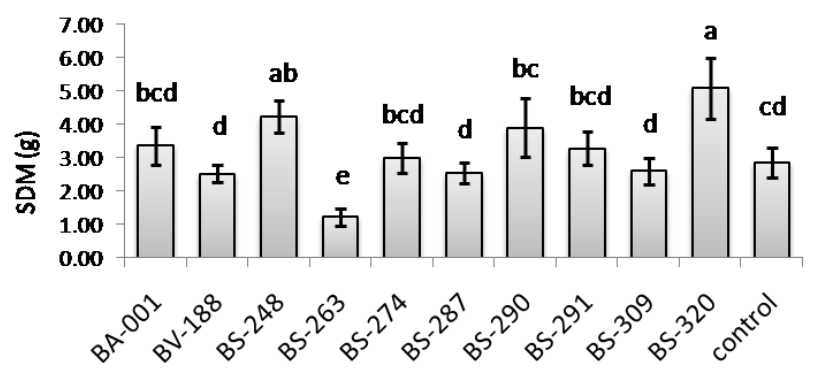

(C)

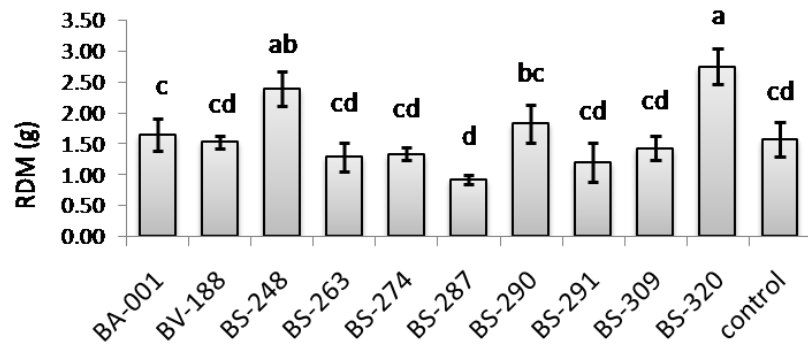

Fig 1. Height (A), shoot dry matter (SDM) (B) and root dry matter (RDM) (C) of maize plants inoculated with 10 endophytic isolates of the genus Bacillus and a control without inoculation from 60 DAS. Bars represent average standard errors. Means with different letters are significantly different according to Duncan's test $(p \leq 0.05)$.

Table 2. Results of soil analyses.

\begin{tabular}{|c|c|c|c|c|c|c|c|c|c|c|}
\hline Conditions & $\mathrm{pH}$ & OM & $\mathrm{P}$ (resin) & $\mathrm{K}$ & $\mathrm{Ca}$ & $\mathrm{Mg}$ & $\mathrm{H}+\mathrm{Al}$ & $\mathrm{BS}$ & CEC & $\mathrm{V}$ \\
\hline & $\mathrm{CaCl}_{2}$ & $\mathrm{~g} \mathrm{dm}^{-3}$ & $m g d m^{-3}$ & \multicolumn{4}{|c|}{$\ldots \ldots \ldots \mathrm{mmol}_{\mathrm{c}} \mathrm{dm}^{3} \ldots \ldots \ldots \ldots \ldots$} & & & $\%$ \\
\hline Greenhouse & 6.5 & 11 & 20 & 0.7 & 19 & 5 & 17 & 24.4 & 42.8 & 64 \\
\hline Field & 6.0 & 23 & 29 & 16 & 10 & 11 & 10 & 21 & 25.4 & 58 \\
\hline
\end{tabular}


(A)

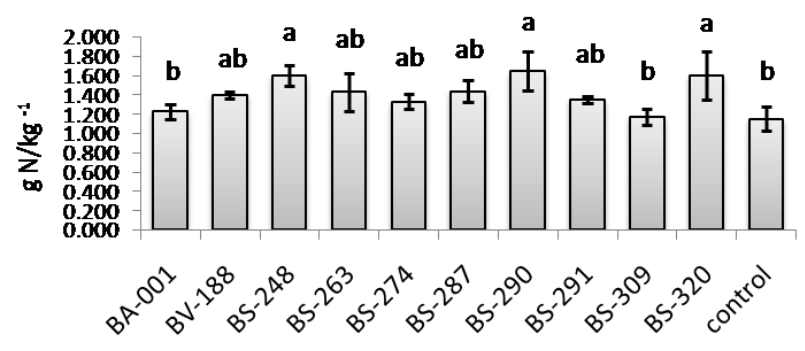

(B)

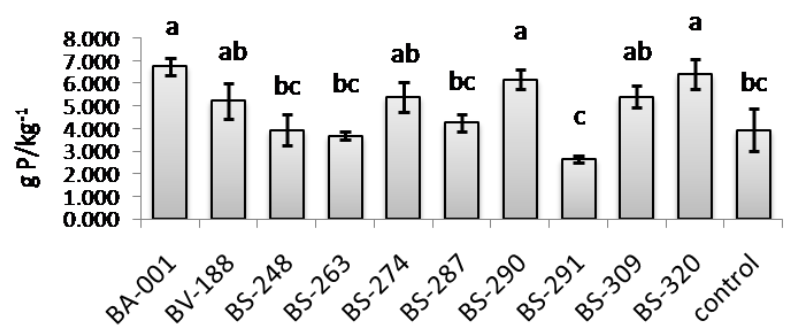

(C)

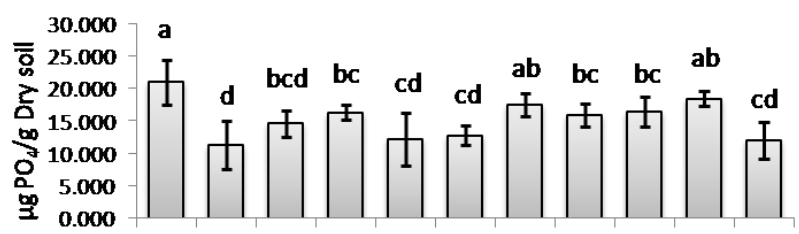

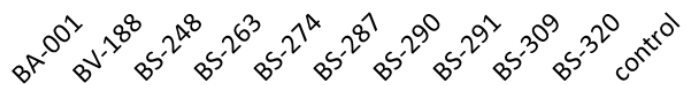

Fig 2. Nitrogen content in roots $(A)$ and phosphorus content in shoots (B) of maize plants and soluble $P$ content in soil (C) of vases inoculated with ten endophytic isolates of the genus Bacillus and a control without inoculation from 60 DAS. Bars represent average standard errors. Means with different letters are significantly different according to Duncan's test $(p \leq 0.05)$.

(A)

(B)
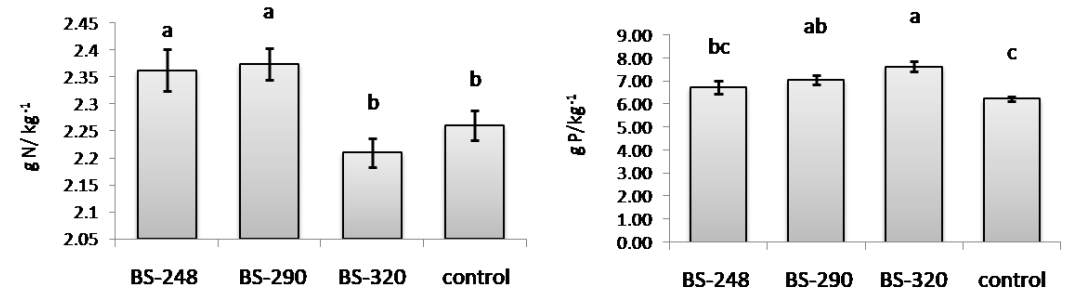

(C)

(D)
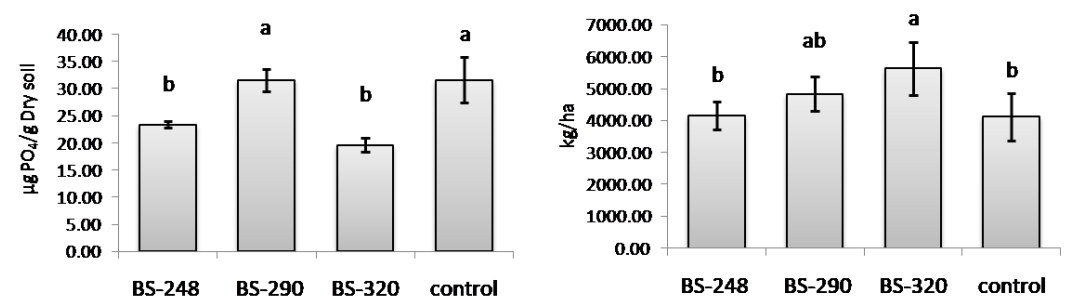

Fig 3. Nitrogen content in shoots (A), phosphorus content in shoots (B), soluble P content in the soil (C) and yield (D) of maize plants inoculated with three B. subtilis strains (BS-248, BS-290 and BS-320) and a control without inoculation. Bars represent average standard errors. Means with different letters are significantly different according to Duncan's test $(p \leq 0.05)$. 


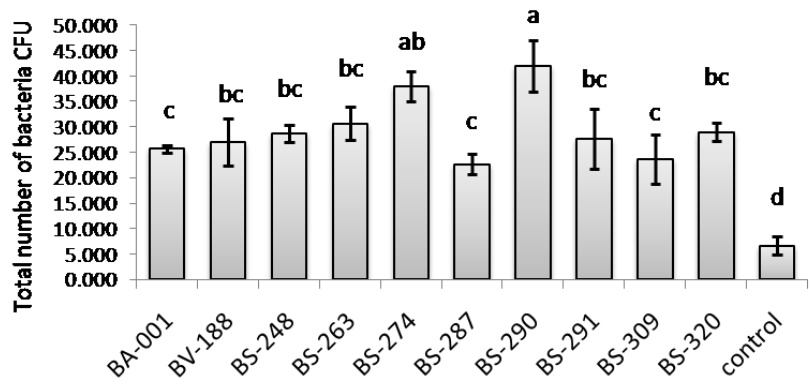

(B)

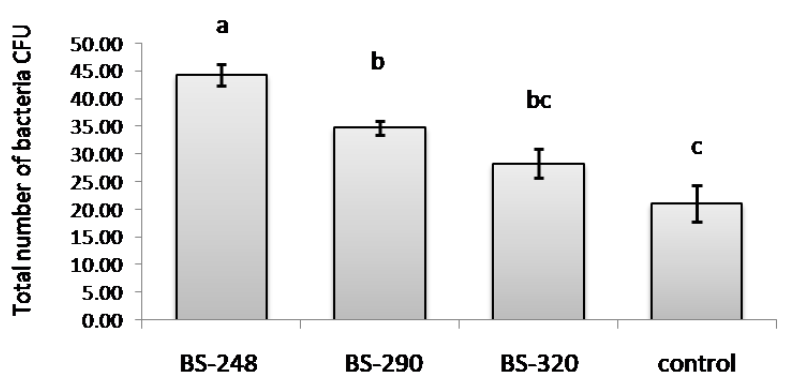

Fig 4. The total number of colony forming units (CFU) of Bacillus spp. in the soil of vases inoculated with ten endophytic Bacillus strains and a control from 60 DAS in phase I (A) and the number of colony forming units (CFU) of Bacillus spp. in the soil under field conditions inoculated with three endophytic B. subtilis isolates (BS-248, BS-290 and BS-320) and a control without inoculation in phase II (B). Bars represent average standard errors. Means with different letters are significantly different according to Duncan's test $(p \leq 0.05)$.

phosphorus sources by solubilization and mineralization. However, many microorganisms have the ability to solubilize phosphorus, and few are able to increase the $P$ content in plants (Anand et al., 2016). In this context, BS-320, BA-001, and BS-290 isolates were the most competent under greenhouse conditions, and under field conditions. The most competent isolates were BS-320 and BS-290. Interestingly, the BS-320 isolate that promoted the highest $\mathrm{P}$ content in SDM also promoted the lowest $P$ content in the soil. These results suggest that this isolate had a close relationship with the plant, making it more efficient in the absorption of phosphorus (Figures $3 \mathrm{~B}-\mathrm{C}$ ).

Most soils have sufficient amounts of plant nutrients, but these compounds are often present in insoluble forms that are unavailable for uptake by plants (Shafi et al., 2017). Rhizobacteria Bacillus species secrete a number of metabolites that can strongly increase nutrient availability to plants (Sivasakthi, et al., 2014), including the improvement of the solubilization of sparingly soluble phosphate compounds in soils, resulting in a higher crop yield and increase in the concentration of soluble P (Wang et al., 2014).

The only isolate that promoted a yield increase compared to the control was BS-320. The yield was increased approximately one ton per hectare when maize received the BS-320 inoculant. This result strongly suggests that this yield increase was the result of many characteristics of this isolate, allowing this organism to promote plant growth. Interestingly, under greenhouse conditions, all treatments that received microbial isolates presented more bacteria than the control, which did not receive any isolates (Figure 4
A). Under field conditions, BS-248 and BS-290 isolates showed more bacteria than control (Figure $4 \mathrm{~B}$ ). Thus, the isolates had the ability to become established in the soil. This characteristic is important for the isolates to interact with the plant and express their capacity to promote plant growth (Bulgarelli et al., 2013). However, the only isolate that promoted a yield increase was BS-320. This result suggests that bacterial establishment in the rhizosphere does not require a large microbial population but rather efficiency and a close interaction with plants.

\section{Materials and Methods}

This study was carried out in two phases (I and II). Phase I corresponded to the experiment conducted in greenhouse conditions with ten Bacillus spp. isolates (Table 1) and a control without inoculation for a period of 60 days after emergence (DAE). Phase II corresponded to the experiment conducted under field conditions using three Bacillus subtilis isolates, which were selected due to their high performance in terms of most parameters evaluated in the greenhouse conditions, compared to those of the control plants without inoculation.

The seeds were obtained from the commercial 2B587PW hybrid (Dow Agro Sciences).

For phase I, the experiment was carried out in a greenhouse belonging to the Laboratory of Microbiology of the Department of Plant Production - UNESP - campus of Jaboticabal, state of São Paulo $\left(21^{\circ} 14^{\prime} 34^{\prime \prime S}, 48^{\circ} 17^{\prime} 54^{\prime \prime W}\right.$ and $613,41 \mathrm{~m}$ a.s.l.). 
The bacterial isolates used in this study belonged to the Laboratory of Microbiology collection of FCAV-UNESP, Jaboticabal Campus. Each bacterial isolate was inoculated in $125 \mathrm{~mL}$ Erlenmeyer flasks containing $60 \mathrm{~mL}$ of nutrient broth $(1.0 \mathrm{~g} / \mathrm{L}$ beef extract; $2.0 \mathrm{~g} / \mathrm{L}$ yeast extract; $5.0 \mathrm{~g} / \mathrm{L}$ peptone; $5.0 \mathrm{~g} / \mathrm{L} \mathrm{NaCl}, \mathrm{pH}$ of $6.8 \pm 0.2$ ), and isolates were incubated at $28^{\circ} \mathrm{C}$ for 24 hours. Subsequently, samples were standardized by using spectrophotometers at $630 \mathrm{~nm}$ (Kloepper et al., 1989). The concentration was adjusted to $1.5 \times 10^{8}$ colony forming units per $\mathrm{mL}^{(\mathrm{CFU} \mathrm{mL}}{ }^{-1}$ ).

Three maize seeds were immersed in each bacterial suspension for 30 minutes. Then, the seeds were sown in vases with $5 \mathrm{dm}^{3}$ of previously sifted Eutrosol soil. Soil fertilization was performed according to chemical analysis (Table 2), and the fertilization recommended for maize crops was applied according to Cantarella et al. (1997). One week after plant emergence, thinning was performed, leaving one plant per pot. The experimental period was 60 days, and bacterial inoculation was performed every 10 days with 10 $\mathrm{mL}$ of bacterial suspension per pot, totaling six bacterial inoculations throughout the experiment. The experimental design included randomized blocks with 11 treatments, three replicates and 33 pots. The treatments were 10 Bacillus spp. isolates, such as $B$. amyloliquefaciens (BA), $B$. velezensis (BV) and $B$. subtilis (BS), and the control without bacterial inoculation.

Plant height was measured from the base of the plant to the apex with the aid of a tape measure. Then, the plants were collected and separated into roots and shoots. Both parts were incubated in an oven with forced air ventilation at $65^{\circ} \mathrm{C}$ for 72 hours until they reached a constant weight. Root and shoot dry matter determinations were made on an analytical scale.

The chlorophyll content was measured by spectrophotometer analysis. For this analysis, some leaf squares were cut $\left(1 \mathrm{~cm}^{2}\right)$. Then, each leaf square was cut into smaller pieces and placed in an Eppendorf tube containing $5 \mathrm{~mL}$ of dimethylformamide. The tubes were stored in a refrigerator at $8^{\circ} \mathrm{C}$ for 72 hours in the dark. Then, an aliquot of $3 \mathrm{~mL}$ of liquid extract was collected for reading in a spectrophotometer at 470, 647 and $664 \mathrm{~nm}$. The chlorophyll content was determined according to the equation proposed by Wellburn (1994).

For nitrogen determination, the plant material was ground in a Willey-type mill (20 mesh) and submitted to leaf nitrogen analysis according to Bremmer (1996) and modified by Bezerra Neto and Barreto (2011), where $0.1 \mathrm{~g}$ of the plant sample was weighed and digested using $7 \mathrm{~mL}$ of sulfuric acid. Subsequently, $10 \mathrm{~mL}$ of distilled water was added. Distillation was performed by using the Kjeldahl method with the aid of $25 \mathrm{~mL}$ of $\mathrm{NaOH}(50 \%)$. The distilled material was recollected in $10 \mathrm{~mL}$ of boric acid as an indicator solution, resulting in $20 \mathrm{~mL}$ of distilled material. Ammonium titration was performed using $0.05 \mathrm{~N} \mathrm{H}_{2} \mathrm{SO}_{4}$ as the standard. The phosphorus concentration $(\mathrm{P})$ was determined by nitroperchloric digestion followed by the molybdate vanadate colorimetric method according to Haag et al. (1975) with a few modifications (Bezerra Neto and Barreto, 2011). A sample of $0.5 \mathrm{~g}$ of plant tissue from the digestor tube was added to $5 \mathrm{~mL}$ of concentrated nitric acid and $1 \mathrm{~mL}$ of concentrated perchloric acid. The mixture was left to rest for one day. Then, complete digestion was performed using a block digester. The material was washed with distilled water to obtain $50 \mathrm{~mL}$ of extract. A reading was performed in a spectrophotometer at $470 \mathrm{~nm}$ using $5 \mathrm{~mL}$ of extract plus 1 $\mathrm{mL}$ of specific reagent composed of a mixture of $5 \%$ ammonium molybdate and $0.25 \%$ ammonium vanadate.

For soil evaluations, soil samples were collected from each pot. Samples were divided into two parts. The first part was used for the phosphorus measurement and was sifted and dried at room temperature. The second part was stored in a refrigerator at $8^{\circ} \mathrm{C}$ to count the total Bacillus spp. Soluble phosphorus was measured according to Watanabe and Olsen (1965), where $0.6 \mathrm{~g}$ of dry soil was sampled and transferred to Erlenmeyer flasks containing $12 \mathrm{~mL}$ of extractor sodium bicarbonate solution and Whatman filter paper. For determination, $2.0 \mathrm{~mL}$ of sodium bicarbonate was pipetted, and $0.2 \mathrm{~mL}$ of sulfur solution $(5 \mathrm{M})$ and $0.8 \mathrm{~mL}$ of $B$ reagent was filtered. Then, the material was incubated at $45^{\circ} \mathrm{C}$ for 20 minutes. Next, a reading was taken using a spectrophotometer at $820 \mathrm{~nm}$. The counting of Bacillus spp. colonies was performed in Petri dishes by serial dilution according to Wollum (1982) associated with the hot shock proposed by Rothfuss et al. (1997) and Barroti and Nahas (2000).

Under greenhouse conditions, the Bacillus spp. selected were those that showed significantly higher numbers in the major evaluated parameters. These Bacillus were selected for use in field conditions.

Phase II was carried out in field conditions at a farm belonging to UNESP - University. Sowing was performed on $8 / 03 / 2017$. Soil was classified as a Eutrosol. Before the start of the experiment, soil was collected and chemically analyzed, and its fertility was measured: $\mathrm{pH}_{\mathrm{CaCL} 2}=6$; organic matter $=23 \mathrm{~g} \mathrm{dm}^{3} ; \mathrm{P}_{\text {resin }}=29 \mathrm{mg} \mathrm{dm} 3 \mathrm{~K}^{3}=16 \mathrm{mmol} \mathrm{dm}{ }^{3} ; \mathrm{Ca}$ $=10 \mathrm{mmol} \mathrm{dm} ; \mathrm{Mg}=11 \mathrm{mmol} \mathrm{\textrm {dm } ^ { 3 }} ; \mathrm{SB}=21 \mathrm{mmol} \mathrm{\textrm {dm } ^ { 3 }}$; cation exchange capacity $=25.4 \mathrm{mmol} \mathrm{dm}^{3}$; and $\mathrm{V} \%=58$. The spacing was $0.90 \mathrm{~m}$ between rows, and six plants were placed per linear meter. Soil fertilization was based on soil analysis according to Cantarella et al. (1997). Each experimental plot was 6 meters in length per $3.6 \mathrm{~m}$ of width. Soil samples were collected before flowering, and the area was $9 \mathrm{~m}^{2}$ per plot. Maize was harvested on June 31, 2017, in the same useful area. Treatments that received $B$. subtilis BS-248, BS-290, and BS-320 followed the same methodology described under greenhouse condition. The concentration

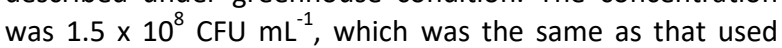
under greenhouse conditions. Four applications of bacteria were made every 10 days via soil with the aid of a costal sprayer. Each plot received $240 \mathrm{~mL}$ of the bacterial mixture and $1,500 \mathrm{~mL}$ of water. The control received water only.

The experimental design was a randomized block design with four isolates and six replicates, resulting in 24 plots with $27 \mathrm{~m}^{2}$ each.

The plants were evaluated for shoot and root dry matter and nitrogen and phosphorus concentrations, and the methodology used was the same as that used in the greenhouse conditions. Plant samples were composed of three plants randomly collected in each plot. For nutrient analysis, leaves below the cob were collected.

Yield was evaluated through manual harvesting from each area. Yield data were adjusted to correspond to $13 \%$ humidity and transformed into hectares $\left(\mathrm{kg} \mathrm{ha}^{-1}\right)$.

The soil analyses were of the phosphorus content and total number of Bacillus spp. according to the methodology described for greenhouse conditions. The soil samples were 
collected as compost samples and taken from the used area from each plot. The preparation and storage of these soil samples were the same as described for greenhouse conditions.

The data obtained were submitted to analysis of variance $(F$ test), in which the treatment averages were compared by Duncan's test with a 5\% significance level using AgroEstat software version 1.0 (Barbosa and Maldonato, 2010).

\section{Conclusion}

Although all isolates presented plant growth promotion abilities, the isolates showed different growth promotion levels. These results were most likely due to slight genotypic differences among isolates. The findings of this study show the importance of understanding the behavior of isolates on individual traits and plant growth. Some isolates, even those that present plant growth promotion characteristics can in some cases unexpectedly inhibit plant development.

\section{Acknowledgment}

We would like to thank CAPES for a scholarship and FAPESP, process number 2014/18313-8.

\section{Conflict of interest}

The authors declare that they have no conflicts of interest.

\section{Funding}

This study was supported by FAPESP, process number 2014/18313-8. This article does not contain any studies with animals performed by any of the authors.

\section{References}

Abdallah RAB, Stedel C, Garagounis C, Nefzi A, JabnounKhiareddine H, Papadopoulou KK, Daami-Remadi M (2017) Involvement of lipopeptide antibiotics and chitinase genes and induction of host defense in suppression of Fusarium wilt by endophytic Bacillus spp. in tomato. Crop Prot. 99: 45-58.

Anand K, Kumari B, Mallick MA (2016) Phosphate solubilizing microbes: an effective and alternative approach as biofertilizers. Int J Pharm Pharm Sci. 8: 37-40.

Angulo VC, Sanfuentes EA, Rodríguez F, Sossa KE (2014) Caracterización de rizobacterias promotoras de crecimiento en plántulas de Eucalyptus nitens. Rev Argent Microbiol. 46(4): 338-347.

Araujo FFD, Guerreiro RT (2010) Bioprospecção de isolados de Bacillus promotores de crescimento de milho cultivado em solo autoclavado e natural. Ciênc Agrotec. 34(4): 837844.

Azevedo JL (1998) Microorganismos endofíticos in: Ecologia Microbiana editora EMBRAPA - CNPMA, Jaguariuna. $p$ 117137.

Barbosa JC, Maldonato Júnior W (2010) AgroEstat: sistema para análises estatísticas de ensaios agronômicos version 1.0. editora UNESP, Jaboticabal.

Barroti G, Nahas E (2000) Total microbial and phosphatesolubilizing population in soil submitted to different cultivation systems. Pesq Agropec Bras. 35(10): 20432050.

Bergey DH, Holt JG (1994) Bergey's manual of determinative bacteriology, 9 ed Williams and Wilkins, Baltimore.

Bezerra Neto E, Barreto LP (2011) Análises químicas e bioquímicas em plantas. Editora UFRPE. Recife, 261p.

Bhattacharyya PN, Jha DK (2012) Plant growth-promoting rhizobacteria (PGPR): emergence in agriculture. World J. Microbiol. Biotechnol. 28(4): 1327-1350.

Bremner JM (1996) Nitrogen-total in: methods of soil analysis Part 3 - Chemical Methods. 5.3: 1085-1121.

Bulgarelli D, Schlaeppi K, Spaepen S, Van Themaat EV, Schulze-Lefert $P$ (2013) Structure and functions of the bacterial microbiota of plants.Annu Rev Plant Biol. 64: 807-838.

Cantarella H, Raij B van, Camargo CEO (1997) Cereais. In: Raij B van, Cantarella H, Quaggio JA, Furlani AMC. Recomendações de calagem e adubação para o Estado de São Paulo - Boletim técnico 100. Instituto Agronômico de Campinas, Campinas. 285p.

Compant S, Clément C, Sessitsch A (2010) Plant growthpromoting bacteria in the rhizo-and endosphere of plants: their role, colonization, mechanisms involved and prospects for utilization. Soil Biol Biochem.42(5):669-678.

CONAB - Companhia Nacional de Abastecimento. Acompanhamento da safra brasileira de grãos, quarto levantamento, janeiro 2018. V. 5, n.10 - Brasília: Conab, 2018, 132p.

Damam M, Kaloori K, Gaddam B, Kausar R (2016) Plant growth promoting substances (phytohormones) produced by rhizobacterial strains isolated from the rhizosphere of medicinal plants. Int J Pharm Sci Rev Res. 37(1): 130-136.

Doty SL (2013) Endophytic yeasts: biology and applications. In: Symbiotic Endophytes. Spring, Berlim, Heidelberg. 335343

Gouda S, Kerry RG, Das G, Paramithiotis S, Shin HS, Patra JK (2018) Revitalization of plant growth promoting rhizobacteria for sustainable development in agriculture. Microbiol Res. 206: 131-140

Haag HP, Sarruge JR, de Oliveira GD, Dechen AR (1975) Nutrição mineral do cajueiro (Anacardium occidentale L.): I-deficiência dos macronutrientes-nota prévia. Anais da Escola Superior da ESA Luiz de Queiroz. 32: 185-190.

Kloepper JW, Lifshitz R, Zablotowicz RM (1989) Free-living bacterial inocula for enhancing crop productivity. Trends Biotechnol. 7(2): 39-44.

Knoth JL, Kim SH, Ettl GJ, Doty SL (2013) Effects of cross host species inoculation of nitrogen-fixing endophytes on growth and leaf physiology of maize. Gcb Bioenergy. 5(4): 408-418.

Lin Y, Watts DB, Kloepper JW, Torbert HA (2018) Influence of Plant Growth-Promoting Rhizobacteria on Corn Growth Under Different Fertility.Commun Soil Sc. Plant Anal. 49(10): 1239-1255.

Nguyen TTN, Némery J, Gratiot N, Strady E, Tran VQ, Nguyen AT, Aimé J, Peyne A (2019) Nutrient dynamics and eutrophication assessment in the tropical river system of Saigon-Dongnai (southern Vietnam). Sci Total Environ, 653: 370-383.

Rocha BCS, Limoeiro AGS, Bueno CES, Souza FS, Braitt AH (2017) In vitro study of the flow rate of five root canal sealers: Endofill, AH Plus, MTA Fillapex, Sealer 26 and Pulp Canal Sealer EWT. Dent Press Endod. 7(2): 67-71. 
Rothfuss F, Bender M, Conrad R (1997) Survival and activity of bacteria in a deep, aged lake sediment (lake constance). Microb Ecol. 33(1): 69-77.

Shafi J, Tian, H, Ji, M (2017) Bacillus species as versatile weapons for plant pathogens: a review. Biotechnol Bioteechnol Equip 31(3): 446-459.

Sivasakthi S, Usharani G, Saranraj P (2014) Biocontrol potentiality of plant growth promoting bacteria (PGPR) Pseudomonas fluorescens and Bacillus subtilis: a review. Afr J Agric Res. 9(16): 1265-1277.

Sureshbabu K, Amaresan N, Kumar K (2016) Amazing multiple function properties of plant growth promoting rhizobacteria in the rhizosphere soil. Int J Curr Microbiol App Sci. 5(2): 661-683.

USDA - Economic Research Service US (2016) Brazil's Corn Industry and the Effect on the Seasonal Pattern of U.S. Corn Exports, AES-93. Brazil's Corn Industry and the Effect on the Seasonal Pattern of U.S. Corn Exports, AES-93. Economic Research Service, 2016. 21p.

Wang L, Feng Z, Wang X, Wang X, Zhang X (2010) DEGseq: an $R$ package for identifying differentially expressed genes from RNA-seq data. Bioinformatics 26(1): 136-138.
Wang T, Liu MQ, Li HX (2014) Inoculation of phosphate solubilizing bacteria Bacillus thuringiensis B1 increases available phosphorus and growth of peanut in acidic soil. Acta Agri Scand. 64(3): 252-259.

Watanabe FS, Olsen SR (1965) Test of an ascorbic acid method for determining phosphorus in water and $\mathrm{NaHCO} 3$ extracts from soil1. Soil Sci Soc Am J. 29(6): 677-678.

Wellburn AR (1994) The spectral determination of chlorophylls $a$ and $b$, as well as total carotenoids, using various solvents with spectrophotometers of different resolution. J Plant Physiol. 144(3): 307-313.

White JF Jr, Torres MS, Sullivan RF, Jabbour RE, Chen $Q$, Tadych M, Irizarry I, Bergen MS, Havkin-Frenkel D, Belanger FC (2014) Occurrence of Bacillus amyloliquefaciens as a systemic endophyte of vanilla orchids. Microsc. Res. Tech. 77(11): 874-885.

Wollum AG (1982) Cultural methods for soil microorganisms, in: Methods of Soil Analysis. Part 2. Chemical and Microbiological Properties. 781-802.

Zafar M, Abbasi MK, Khan MA, Khaliq A, Sultan T, Aslam M (2012) Effect of plant growth-promoting rhizobacteria on growth, nodulation and nutrient accumulation of lentil under controlled conditions. Pedosphere 22(6): 848-859. 